\title{
Performance and selected blood parameters of broiler chickens fed diets with skullcap (Scutellaria baicalensis Georgi) root
}

\author{
B. Króliczewska ${ }^{1,3}$, P. Jankowska', W. Zawadzki' and J. Oszmiański
}

\author{
Wroclaw Agricultural University. \\ 'Department of Animal Physiology, \\ 'Department of Fruit and Vegetables and Grain Technology \\ C.K. Norwida 31, 50-375 Wrockow, Poland
}

\begin{abstract}
One hundred and twenty one-day-old male broiler chickens were allocated into four groups, 5 replicates of 6 birds in each. (hickens were fed either a control diet or the same diet with the addition of 5,10 or $15 \mathrm{~g}$ per kg of dried skullcap (Scutellaria haicalensis Georgi - SCR) root. The addition of 5 and $10 \mathrm{~g} \mathrm{SCR}$ per $\mathrm{kg}$ diet had little effect on performance and blood parameters. In the group fed the diet with $15 \mathrm{~g} \mathrm{SCR}$, body weight gain, red blood cell count and haemoglobin level was higher $(\mathrm{P}<0.05)$, while the fIDL, LDL, and total cholesterol levels in blood serum $(\mathrm{P}<0.05)$ were lower than in the control group. The glucose level in blood serum was variable, aspartate aminotransferase and alkaline phosphatase activities were similar, while alanine aminotransferase activity, higher $(P<0.05)$ in all groups fed diets with SCR than in the control group.
\end{abstract}

KEY WORDS: skullcap root, blood, performance, broiler chickens

\section{INTRODUCTION}

In recent years, new additives of plant origin, considered to be natural products that consumers would accept, have been offered to livestock producers as an alternative for antibiotic growth promolers. For some of them, beneficial effects on health and productivity, including feed conversion ratio, have been reported (Hernández. et al., 2004). Skullcap (Scutellaria baicalensis Georgi) root (SCR) is well known and widely applied in China and Japan. It has a particularly high content of flavonoids, which are modifiers of inflammatory processes, prevent bacterial infections and have antiviral, antitumor and antioxidative properties as well as hepatoprotecive effects (Gao et al., 1999; Chan et. al., 2000; Bochorakova

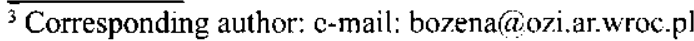


et al., 2003). The objective of this study was to evaluate the effect of SCR on the performance of broiler chickens and selected blood parameters.

\section{MATERIAL AND METHODS}

One hundred and twenty one-day-old male Hubbard-ISA broiler chickens were randomly allocated into four groups, each group comprised 5 cages (replicates) with 6 birds. The birds were fed either a control basal diet (Table 1) or the basal diet with the addition of 5,10 or $15 \mathrm{~g}$ of ground dried SCR per kg diet. Starter diets were fed from day 1 to 14 of life, grower diets from day 15 to 42 of life. Body weight and feed intake were measured at weekly intervals and body weight gain (BWG) and feed conversion ratio (FCR) were calculated. At the end of the experiment, blood samples were collected from the $v$ jugularis from 10 birds in each group. Glucose, total protein, triglycerides, HDL, LDL and total cholesterol contents were measured in serum using BioSystems kits. The activity of alanine aminotransferase (ALT), aspartate aminotransferase (AST) and alkaline phosphatase (AP) were determined with the use of Aqua Medica kits and a Pharmacia Biotech Ultrospec 2000 spectrophotometer. The effects of dietary treatments were compared by one-way ANOVA (Statistica, 1997).

TABLE 1

Composition of control basal diets, $\mathrm{g} / \mathrm{kg}$ DM

\begin{tabular}{lrc}
\hline Ingredients & Starter & (irower \\
\hline Maize & 375.0 & 510.0 \\
Wheat & 220.0 & 150.0 \\
Soyabean meal & 284.8 & 230.0 \\
Meat meal & 33.1 & 46.6 \\
Plant oil & 50.0 & 30.0 \\
Calcium carbonate & 2.0 & 3.0 \\
Dicalcium phosphate & 19.5 & 15.0 \\
NaCl & 3.0 & 3.0 \\
DL-methionine & 2.6 & 2.4 \\
Vitamin-mineral premix & 10.0 & 10.0 \\
\hline
\end{tabular}

' vitamin-mineral premix provided per $\mathrm{kg}$ of diet: vit. A $10000 \mathrm{IU}$. vit. D, $2500 \mathrm{IU}, \mathrm{mg}$ : vit. E 35 , pantothenic acid 10, $\mathrm{B}_{1} 3, \mathrm{~B}_{2} 7, \mathrm{~B}_{6} 4, \mathrm{~B}_{12} 0.01$, niacin 25 , folic acid 1.5 , choline $950, \mathrm{~K} 1$, biotin 0.15 , and $\mathrm{Mn} 60, \mathrm{Zn} 50, \mathrm{Fe} 40, \mathrm{Cu} 6, \mathrm{Se} 0.15$

\section{RESULTS}

In the groups fed diets with 5 and $10 \mathrm{~g}$ of added SCR, feed intake was significantly lower, but BWG was similar as in the control group, while in the group 
fed the diet with $15 \mathrm{~g}$ of SCR, feed intake was similar and BWG was significantly higher $(\mathrm{P}<0.05)$ in comparison with the control group (Table 2$)$. The addition of 5 and $10 \mathrm{~g}$ SCR per $\mathrm{kg}$ dict had little effect on the measured blood parameters, whercas in the group fed the diet with $15 \mathrm{~g}$ SCR, the red blood cell count and haemoglobin level were higher $(\mathrm{P}<0.05), \mathrm{HDL}, \mathrm{LDL}$ and total cholesterol levcls in serum were lower $(\mathrm{P}<0.05)$ than in the control group. The glucose level was variable, $\Lambda \mathrm{LT}$ and AP activities were similar, while AST activity, higher than in the control group in all of the groups fed SCR diets.

TABLE 2

Performance of chickens, 1 to 42 days of age

\begin{tabular}{lccccc}
\hline \multirow{2}{*}{ Parameter } & \multicolumn{5}{c}{ Dictary trcatments } \\
\cline { 2 - 6 } & control & $5 \mathrm{~g} \mathrm{SCR}$ & $10 \mathrm{~g} \mathrm{SCR}$ & $15 \mathrm{~g} \mathrm{SCR}$ & SEM \\
\hline Body weight gain, g & $1741^{\mathrm{a}}$ & $1744^{\mathrm{b}}$ & $1733^{\mathrm{a}}$ & $1816^{\mathrm{c}}$ & 34.3 \\
Feed intake, g & $3055^{\mathrm{a}}$ & $2942^{\mathrm{b}}$ & $2986^{\mathrm{b}}$ & $3138^{\mathrm{a}}$ & 5.27 \\
FCR, g feed/g BWG & 1.79 & 1.68 & 1.72 & 1.72 & 0.01 \\
\hline
\end{tabular}

a,h means in rows with different letters differ significantly at $\mathrm{P}<0.05$

TABLE 3

Haematological and biochemical parameters in blood of chickens

\begin{tabular}{lccccc}
\hline \multirow{2}{*}{ Parameter } & \multicolumn{5}{c}{ Dictary treatments } \\
\cline { 2 - 6 } & Control & $5 \mathrm{~g} \mathrm{SCR}$ & $10 \mathrm{~g}$ SCR & $1.5 \mathrm{~g} \mathrm{SCR}$ & SEM \\
\hline Red blood ccll count. T/L & $2.27^{\mathrm{a}}$ & $2.19^{\mathrm{a}}$ & $2.32^{\mathrm{a}}$ & $2.40^{\mathrm{b}}$ & 0.03 \\
Haematocrit, L/L & 0.28 & 0.28 & 0.27 & 0.29 & 0.01 \\
Haemoglobin concentration, g/L & $8.74^{\mathrm{a}}$ & $9.21^{\mathrm{a}}$ & $9.09^{\mathrm{a}}$ & $9.69^{\mathrm{b}}$ & 0.28 \\
White blood ccll count, g/L & 41.5 & 38.6 & 30.9 & 36.7 & 2.34 \\
Total cholesterol, mmol/L & $3.13^{\mathrm{a}}$ & $2.72^{\mathrm{a}}$ & $2.98^{\mathrm{a}}$ & $2.48^{\mathrm{b}}$ & 0.06 \\
HDL cholesterol, mmol/L & $2.20^{\mathrm{a}}$ & $1.72^{\mathrm{a}}$ & $1.84^{\mathrm{b}}$ & $1.75^{\mathrm{b}}$ & 0.09 \\
LDL cholesterol, mmol/L & $0.90^{\mathrm{a}}$ & $0.93^{\mathrm{a}}$ & $1.10^{\mathrm{a}}$ & $0.64^{\mathrm{b}}$ & 0.16 \\
Triglycerides, mmol/L & 0.32 & 0.52 & 0.24 & 0.49 & 0.04 \\
Total protein, g/L & 331 & 3.09 & 2.94 & 3.28 & 0.23 \\
Glucose, mmol/L & $230.76^{\mathrm{a}}$ & $191.7^{\mathrm{b}}$ & $216.9^{\mathrm{a}}$ & $194.4^{\mathrm{b}}$ & 15.20 \\
Aspartate aminotransferase, U/L & 239.2 & 232.4 & 215.9 & 210.2 & 16.05 \\
Alanine aminotransferase, U/l. & $16.02^{\mathrm{a}}$ & $27.84^{\mathrm{b}}$ & $40.69^{\mathrm{b}}$ & $26.24^{\mathrm{b}}$ & 4.09 \\
Alkaline phosphatase, U/l. & 727.6 & 814.5 & 728.8 & 878.5 & 63.9 \\
\hline
\end{tabular}

$a, b$ means in rows with different letters differ significantly at $\mathbf{P}<0.05$

\section{DISCUSSION}

The decrease in the blood cholesterol level is in agreement with the results of Hamada et al. (1993), who reported that flavonoids lowered the quantity of cholesterol in blood and of Harborne et al. (1986), who reported that flavonoids lowered the LDL level in blood. Also, according to Tang and Eisenbrandt (1992) flavonoids from skullcap root can lower the total blood cholesterol content. A high 
serum LDL level is associated with an increased risk of cardiovascular diseases, so lowering this fraction may lower broiler mortality. It seems that the amount of flavonoids in diets with 5 or $10 \mathrm{~g} \mathrm{SCR}$ was too low to affect performance, but chickens fed the diet with highest amounts of SCR had a higher final body weight in comparison with the control group. There was no information in the available literature about the influence of $S$. baicalensis (Georgi on the performance of chickens, but Hernandez et al. (2004) reported that the addition of vegetable extracts from the Labiatae family to broiler diets positively affected the growth rate.

The results of the study indicated that addition of $15 \mathrm{~g}$ of sculleap root to the diet may positively affect the growth rate and blood parameters of broiler chickens.

\section{REFERENCES}

Bochorakova II., Paulova II., Slanina J., Musil P., Taborska E., 2003. Main flavonoids in the root of Scutellaria baicalensis cultivated in Europe and their comparative antiradical properties. Photother. Res. 17, 640-644

Chan F.L., Choi H.L., Chen Z.Y., Chan I'.S., Huag Y., 2000. Induction of apoptosis in prostate cancer cell lines by a flavonoid baicalin. Cancer Lett. 160,219-228

Gao Z., Huang K., Yang X., Xu H.. 1999. Free radical scavenging and anti-oxidant activities of flavonoids extracted from the radix of Scutellaria baicalensis Georgi. Biochem. Biophys. Acta 1472, 643-650

Hamada H., Hiramatsu M., Mori A., 1993. Free radical scavenging action of baicalein. Arch. Biochem. Biophys. 306, 261-266

Harborne J.B., 1986. Nature, distribution and function of plant flavonoids. Prog. Clin. Biol, Res. 213, 15-24

Ilernández. F., Madrid J., (iarcia V., Orengo J., Megias M.D., 2004. Influence of two plant extracts on broiler performance, digestibility, and digestive organ size. Poultry Sci. 83, 169-174

StatSoft, Inc., 1997. Statistica for Windows: StatSoft, Inc., Tulsa, OK

Tang W., Eisenbrandt G., 1992. Flavonoids in Chinese Drugs of Plant Origin. Chemistry, Pharmacology and Use in Traditional and Modern Medicine. Springer-Verlag, Berlin, pp. 919-929

\section{STRESZCZENIE}

Wyniki odchowu i wybrane wskaźniki krwi kurcząt brojlerów żywionych mieszankami z dodatkiem korzenia tarczycy bajkalskiej

Sto dwadzieścia jednodniowych kogutków brojlerów podzielono na cztery grupy, w każdej 5 powtórzeń po 6 plaków. Kurczęta żywiono dietą kontrolną lub tą samą dietą z dodatkiem 5, 10 lub $15 \mathrm{~g}$ wysuszonego i zmiclonego korzenia tarczycy bajkalskiej (SCR). Dodatek 5 i $10 \mathrm{~g}$ SCR na kg diety miał niewielki wpływ na wydajność odchowu i wskaźniki krwi. W grupic żywioncj dietą 7 dodatkiem $15 \mathrm{~g}$ SCR przyrost masy ciała, liczba krwinek czerwonych i hemoglobiny byly wyżze $(\mathrm{P}<0,05)$, a poziom cholesterolu całkowitego i jego frakcji LDL i IIDL niższy $(\mathrm{P}<0,05)$ w porównaniu $\mathrm{z}$ grupa kontrolną. Poziom glukozy w osoczu krwi był zmienny, aktywność AST i AP podobna, natomiast aktywność aminotransferazy alaniny była wyższa $(\mathrm{P}<0,05)$ we wszystkich grupach żywionych dietami z SCR niż w grupie kontrolnej. 